DOI 10.23859/2587-8344-2018-2-4-9

УДК 94(47).084.3

Цветков Василий Жанович

Доктор исторических наук, профессор,

Московский педагогический государственный университет

(Москва, Россия)

tsvetcov@rambler.ru

Tsvetkov Vasily

Doctor of Historical Sciences, Professor,

Moscow State Pedagogical University

(Moscow, Russia)

tsvetcov@rambler.ru

Цветкова Елена Александровна

Кандидат экономических наук, доцент,

Московский педагогический государственный университет

(Москва, Россия)

tsvetcov@rambler.ru

Tsvetkova Elena

Candidate of Economic Sciences (PhD), Associate Professor,

Moscow State Pedagogical University

(Moscow, Russia)

tsvetcov@rambler.ru
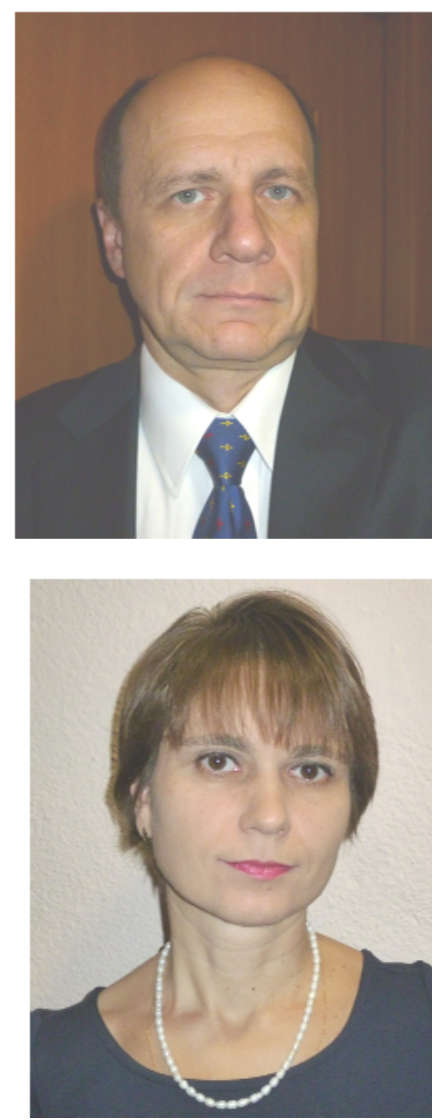

Особенности регионального продовольственного рынка в Крыму и Северной Таврии в годы Гражданской войны (весна - осень 1920 года)*

\title{
Features of the Regional Food Market in the Crimea and Northern Taurida during the Civil War (Spring - Autumn 1920)
}

Аннотация. В статье рассматриваются проблемы функционирования региональных рынков на белом Юге России во время Гражданской войны, в заключительный ее период (весна

* Для цитирования: Цветков В.Ж., Цветкова Е.А. Особенности регионального продовольственного рынка в Крыму и Северной Таврии в годы Гражданской войны (весна - осень 1920 года) // Historia Provinciae - Журнал региональной истории. 2018. Т. 2. № 4. С. 178-198. DOI: $10.23859 / 2587-8344-2018-2-4-9$

For citation: Tsvetkov, V., and E. Tsvetkova, "Features of the Regional Food Market in the Crimea and Northern Taurida during the Civil War (Spring - Autumn 1920)". Historia Provinciae - The Journal of Regional History, vol. 2, no. 4 (2018): 178-198, http://doi.org/ 10.23859/25878344-2018-2-4-9

(C) Цветков В.Ж., Цветкова Е.А., 2018

(C) Tsvetkov V. and E. Tsvetkova, 2018 
- осень 1920 г.), связанный с деятельностью Главнокомандующего Русской армией, Правителя Юга России генерала П.Н. Врангеля. Территориальные рамки статьи - Таврическая губерния (Крым и Северная Таврия). Анализируется динамика цен на основные сельскохозяйственные товары, их соотношение с ценами на промышленные товары, изменения спроса и предложения. Приводимые статистические данные в своей значительной части впервые вводятся в научный оборот. Показано влияние изменений в положении на фронте белой армии на динамику рыночных цен. Учитываются региональные особенности положения сельского хозяйства в белом Крыму и в Северной Таврии в 1920 году.

Ключевые слова: региональная экономика, история экономики, Гражданская война, крестьянство, рыночные цены, сельскохозяйственные и промышленные товары, Белое движение, П.Н. Врангель.

Abstract. The article is devoted to the issues of the regional markets in the 'White' South of Russia during the final period of the Civil War (spring-autumn 1920) which is associated with the activities of the commanding general of the anti-Bolshevik White Army in Southern Russia Pyotr Wrangel. The territorial scope of the article covers the Taurida Governorate (the Crimea and Northern Taurida). The dynamics of prices for basic agricultural products, their correlation with the prices for manufactured goods, as well as changes in demand and supply are analysed. The given statistical data are introduced into the scientific discourse for the first time. The influence is shown with regards to the changes in the situation at the front of the White Army, on the dynamics of the local market prices. The regional features of the agricultural situation in the White Crimea and the Northern Taurida in 1920 are considered.

Keywords: Regional economics, history of economics, Civil War, peasantry, market prices, agricultural and industrial goods, White movement, Pyotr Wrangel

\section{Введение}

Анализ экономического положения в регионах, занятых белыми правительствами, до настоящего времени остается малоизученной темой. Однако для комплексного изучения проблем, связанных как с историей Гражданской войны в России в целом, так и Белого движения в частности, необходим анализ данных о состоянии белого тыла. Это позволит составить представление о степени поддержки населением белой власти, о перспективах вооруженного противостояния с Красной Армией, о проведении тех или иных мероприятий экономической политики с учетом региональной специфики.

В отечественной историографии проблематика экономического положения белого Крыма и Северной Таврии в 1920 г. весьма активно изучалась в 1920 начале 1930-х гг. ${ }^{2}$. Однако в последующие десятилетия сугубо экономические

${ }^{1}$ Шафир Я. Экономическая политика белых (Крымский опыт) // Красная новь. 1921. №2; Гуковский $A$. К истории аграрной политики русской контрреволюции (Аграрная политика правительства Врангеля) // На аграрном фронте. 1927. № 7; Гензель П.П. Крым в финансово- 
исследования оказались свернуты. Не уделяла экономическим проблемам должного внимания и зарубежная историография, ограничиваясь изданиями по социально-политической или военно-политической проблематике ${ }^{2}$. Лишь за последние десятилетия экономическая тематика снова востребована ученымиисториками $^{3}$. Но, тем не менее, необходимо уделять этим вопросам больше внимания. В этом отношении важно сотрудничество историков и экономистов, использование междисциплинарных связей.

Данная статья тематически продолжает публикацию авторов на страницах «Экономического журнала», подготовленную в 2017 году ${ }^{4}$, и представляет собой часть готовящейся к изданию монографии по проблемам экономической, аграрно-крестьянской политики в белом тылу в период 1917-1920 гг.

\section{Основная часть}

База источников по данному периоду вполне достаточна, чтобы составить общее представление о динамике спроса и предложения в Крыму и Северной Таврии, росте цен на основные продовольственные товары, состоянии рынка в прифронтовых районах Северной Таврии и «тыловых», защищенных перекопскими укреплениями крымских уездах. После расформирования Управления Продовольствия все дела, связанные со снабжением армии и тыла в Таврии, находились в ведении Главного Начальника Снабжении генерал-майора П.Э. Вильчевского 5 . Данные о положении продовольственного рынка содержатся в фондах Управления Земледелия и Землеустройства (УЗиЗ), Управления продо-

экономическом отношении в 1918-20 гг. // Экономист. 1922. № 3; Шеф К. Крымский полуостров - последняя база южнорусской контрреволюции // Война и революция. 1927. № 7.

${ }^{2}$ Lehovich D. White against Red. The life of general Anton Denikin. N.Y.: W.W. Norton, 1974; Smele J.D. Civil war in Siberia. The anti-Bolshevik government of Admiral Kolchak, 19181920. Cambridge: Cambridge University Press, 1996; Pereira N.G.O. White Siberia. The Politics of Civil War, London: Jonathan Cape, 1996; Figes O. A people's tragedy: The Russian revolution 1891-1924. London: Penguin Books, 1996; Gatrell P. Russia's First world war: A social and economic history. Harlow: Pearson Education Limited, 2005.

${ }^{3}$ Рынков В.М. Финансовая политика антибольшевистских правительств Востока России. Новосибирск: Институт истории СО РАН, 2006; Рынков В.M. Земельные органы антибольшевистских правительств в Сибири (июнь 1918 - декабрь 1919 г.). Сборник документов. Новосибирск: Сибпринт, 2017; Карпенко C.B. Очерки истории Белого движения на Юге России (1917-1920 гг.). М.: Издательство Ипполитова, 2003.

${ }^{4}$ Цветков В.Ж., Цветкова Е.А. Особенности региональных продовольственных рынков в период Гражданской войны на Юге России в 1919 - начале 1920 гг. // Экономический журнал. 2017. № 3 (47).

${ }^{5}$ Врангель П.Н. Записки // Белое дело. Летопись белой борьбы. Т. VI. Берлин: Медный всадник, 1928. С. 20, 41. 
вольствия (УП) и Управления Торговли и Промышленности (УТиП) Государственного архива Российской Федерации (ГА РФ) ${ }^{6}$.

Специфика таврического продовольственного рынка в 1920 г. заключалась в следующем: здесь, в отличие от предшествующего периода 1919 г., отсутствовал чрезвычайный спрос на продукты со стороны более северных районов Малороссии и Черноземного Центра, поэтому организация продовольственного снабжения ограничивалась границами Таврической и части Екатеринославской губерний. С другой стороны, усиленно рос спрос на продовольствие со стороны армии и гражданского населения Таврии, выросшего за период Гражданской войны (в результате притока беженцев со всей Европейской России - около 500000 чел.) в несколько раз ${ }^{7}$.

Большие надежды на зерновые запасы возлагало врангелевское Правительство Юга России в связи с необходимостью организации товарообмена с заграницей для получения вооружения, мануфактуры, топлива, сельскохозяйственного инвентаря и т.д. Экспорт зерна и других продуктов осуществлялся не за счет закупок у крестьян, а, главным образом, за счет сохранившихся еще со времени Первой мировой войны продовольственных запасов. Следовательно, влияние аграрно-крестьянской политики на осуществлявшийся вывоз продуктов с белого юга России было ничтожным. Тем не менее, как отмечалось в большинстве свидетельств белых эмигрантов, разведсводках РККА, исследованиях советских историков, расчеты на то, что предложение со стороны крестьянских хозяйств будет настолько большим, что сможет удовлетворить не только внутренний, но и внешний рынки, не оправдались ${ }^{8}$.

Темпы инфляции в белой Таврии 1920 г. приняли катастрофический характер. Большой скачок в насыщении рынка необеспеченными денежными знаками произошел зимой 1919/20 гг. ${ }^{9}$ Но если в марте 1920 г. количество бумажных купюр, выпущенных в обращение, равнялось 30 млрд, то к августу оно выросло уже до 50 млрд. А с 15 сентября по 15 октября Феодосийской денежной экспедиции был сделан заказ на выпуск 60 млрд денежных знаков ${ }^{10}$. Непродуманная финансовая политика, подрывавшая хозяйство Таврии, была одним из главных факторов почти непрерывного роста цен на продовольствие, не говоря уже о промышленных товарах.

\footnotetext{
${ }^{6}$ Государственный архив Российской Федерации (ГА РФ): Ф. 355 (Управление земледелия и землеустройства), Ф. 356 (Управление торговли и промышленности), Ф. 879 (Управление продовольствия).

${ }^{7}$ Крестьянский путь. Симферополь. 1920. 11 сентября.

${ }^{8}$ Шафир Я. Экономическая политика белых (Крымский опыт) // Красная новь. 1921. №2, С. 111; Гуковский А. К истории аграрной политики русской контрреволюции (Аграрная политика правительства Врангеля) // На аграрном фронте. 1927. № 7. С. 69-75.

${ }^{9}$ Шафир Я. Указ. соч. С. 117.

${ }^{10}$ Великая Россия. Севастополь. 1920. 21 сентября; Гензель П.П. Указ. соч. С. 108.
} 
Внутренний рынок продолжал работать на декларированных еще деникинским правительством принципах «свободы торговли», подтвержденных приказом Главнокомандующего Вооруженными силами Юга России (ВСЮР) генерал-лейтенанта П.Н. Врангеля № 59 от 25 июня 1920 г. $^{11}$ Однако в условиях промышленной и транспортной разрухи, военных действий и под влиянием указанных выше экономических, финансовых факторов свободный рыночный товарообмен приобретал в белой Таврии все более и более спекулятивный характер.

В марте цены в Крыму существенно выросли по сравнению с осенним уровнем 1919 г. Средняя цена фунта пшеничного хлеба составляла 10-15 руб. (4-6 руб. в октябре 1919 г.), пуд муки-сеянки - 695 руб. (150-200 руб. в октябре), фунт говядины - 175 руб. (20 руб.), масло сливочное - 850 руб. (250 руб.), сахар-песок - 550 руб. (65 руб.) фунт ${ }^{12}$. С эвакуацией в Крым ВСЮР и гражданских беженцев из Новороссийска цены резко возросли. Прирост составил за март $100 \%$, апрель - $130 \%$, май $-190 \%{ }^{13}$. Усиленный, необеспеченный ничем, кроме обесцененных дензнаков, спрос на продукты вызывал их подорожание. В мае цены на эти же категории продуктов составляли: 108 руб. - фунт пшеничного хлеба, 3350 руб. - пуд муки-сеянки, 750 руб. - фунт говядины, 3750 руб. фунт сливочного масла, 1200 руб. - фунт сахарного песка. Фунт керосина стоил 400 руб., десяток яиц - 1000 руб., кварта молока - 300 руб. ${ }^{14}$ Даже такой доступный для Крыма продукт как рыба-камса (основной продукт рациона Русской армии генерала Врангеля в апреле - мае) стоила в мае 1000 руб. ${ }^{15}$

Уже в первые дни после Новороссийской эвакуации на заседании Совета при Главкоме ВСЮР генерале Врангеле (заседание 9 апреля) генерал Вильчевский констатировал, что «наличные запасы в Крыму муки позволяют предполагать, что муки хватит до нового урожая, при условии расходования до одного фунта в сутки на человека». Необходимо было введение нормированного распределения продуктов. На заседании было решено: воспретить выпечку хлебных изделий, вывоз хлебных злаков из пределов Крыма, уменьшить потребление мяса введением 3 постных дней в неделю (среда, пятница, суббота) ${ }^{16}$. Приказом Главкома ВСЮР № 2959 от 16 апреля вводилась карточная система про-

${ }^{11}$ Таврические губернские ведомости. Симферополь. 1920. 20 июля.

12 Хвойнов П. Рабочее движение и профсоюзы в Крыму в 1920 г. // Антанта и Врангель. ГИЗ, М.-Пг., 1923. С. 226-227.

${ }^{13}$ Там же.

${ }^{14}$ Там же; ГА РФ. Ф. 879. Оп. 1. Д. 89. Л. 67-71.

${ }^{15}$ ГА РФ. Ф. 879. Оп. 1. Д. 84. Л. 1-5; Д. 89. Л. 70-71.

${ }^{16}$ Начало врангелевщины // Красный архив, т. 2 (21), 1927. ГИЗ М.-Л. С. 179; Таврические губернские ведомости. Симферополь. 1920. 23 апреля. 
дажи хлеба, устанавливалась выпечка хлеба из пшеничной муки с добавлением 200 золотников ${ }^{17}$.

Попытка введения карточной системы на хлеб стала фактически единственной попыткой ограничить принципы свободной торговли на белом юге России в 1919-1920 гг. (не считая приказа предшественника Врангеля, генерала А.И. Деникина об уголовной ответственности за спекуляцию). Результаты подобных попыток оказались довольно скромными. Введение карточной системы на хлеб в расчете 1 фунт на человека в день (мера эта не касалась армии, которая должна была получать прежние нормы хлебного довольствия - 2 фунта хлеба на человека) было поручено органам городского самоуправления. Однако из всех городов Крыма лишь в Севастополе были введены карточные ограничения ${ }^{18}$. Но это не улучшило продовольственное положение города, хлеб стал исчезать из продажи. Репрессивных мер в отношении укрывателей продуктов не предпринималось, а собственные продовольственные запасы городских управ были невелики.

Недостаток продовольствия стал одной из главных причин майского наступления Русской армии, «выхода на просторы Северной Таврии» ${ }^{19}$. Необходимость наступления объяснялась тем, что Крым мог существовать только благодаря организованному подвозу продуктов животноводства из Северной Таврии, топлива из Донбасса, зерновых излишков с Кубани. Поэтому без налаженного привоза этих товаров, сколько-нибудь длительное пребывание армии и беженцев в изолированном Крыму представлялось невозможным ${ }^{20}$.

С занятием хлебородных уездов Северной Таврии, захватом крупных продовольственных складов в Мелитополе, Хорлах, Скадовске и Геническе удалось наладить отправку продуктов в Крым и тем самым облегчить трудности продовольственного рынка. Рост цен в июне-июле замедлился (27 \% в июне по отношению к маю, в июле прирост составил 0,5-1\%) ${ }^{21}$ В прессе появились обнадеживающие сообщения о преодолении хлебного кризиса ${ }^{22}$. В правительственных кругах выдвигались предположения о возможном широкомасштабном экспорте таврического зерна ${ }^{23}$. Однако местными уполномоченными УЗиЗ и УТиП высказывались более скромные суждения: «...закупочные цены в Северной Таврии значительно ниже, чем в Крыму (ситуация обратная 1919 г., когда

17 Таврические губернские ведомости. Симферополь. 1920. 23 апреля; Врангель П.Н. Указ. соч. С. 31.

${ }^{18}$ Юг России. Севастополь. 1920. 29 июля.

${ }^{19}$ РГВА. Ф. 1574. Оп. 1. Д. 479. Л. 56, 74.

${ }^{20}$ Гуковский А. В тылу «вооруженных сил Юга России»// Красный архив, т. 3 (34). Центрархив. 1929 г. С. 226; ГА РФ. Ф. 356. Оп. 1. Д. 23. Л. 8-9

${ }^{21}$ Хвойнов П. Указ. соч. С. 226-227.

${ }^{22}$ Юг России. Севастополь. 1920. 30 мая; Великая Россия. Севастополь. 2 июля 1920 г.

${ }^{23}$ Юг России. Севастополь. 1920. 2 июля; Гензель П.Н. Указ. соч. С. 112. 
приход белых обычно означал понижение «неоправданно высоких» цен - прим. aвm.), мука пшеничная предлагается по 2500-2750 руб. (в Крыму - 3700 руб.) пуд, ячмень до 250 руб. (в Крыму не ниже 300 до 1000 руб.)..., запасы большие, население отказывается сдавать хлеб за деньги. Для использования хлебных ресурсов Северной Таврии очевидно необходимо снабдить местную продовольственную организацию большим количеством товаров, ходких среди сельского населения...» ${ }^{24}$

Аналогичное положение отражал доклад уполномоченного по продовольствию в Крыму (июнь): «...закупать хлеб за деньги не просто, невозможно. Цены на хлеб выросли невероятно. В Перекопском уезде ... на 10 июня - на пшеницу до 1000 руб. за пуд... Крестьяне требуют в обмен на хлеб керосин, сахар, чай, мануфактуру, обувь, лопаты, пилы и сельхозорудия, помещики требуют главным образом машины, орудия и материалы производства (примечательная разница в требованиях товарообмена - крестьянские хозяйства уже не рассчитывают на получение машин, а довольствуются элементарными орудиями труда, а ведь до 1914 г. Таврическая губерния занимала ведущее место в России по обеспеченности крестьянских хозяйств сельскохозяйственными машинами прим. авт.), все воздерживаются от продажи хлеба...» 25

В этой ситуации указывалось на возможность ввоза части продуктов из-за границы, планировалось «организовать закупки мяса и жиров на Балканах», поскольку собственные запасы мяса в Крыму были невелики, а закупочные цены составляли 25-30 тыс. руб. за пуд говядины и 100-130 тыс. руб. за пуд сала. Предполагалось осуществить товарообмен на условиях поставки на Балканы соли, имевшейся в Крыму в изобилии. На этих же условиях предполагалось осуществить за рубежом закупку сахара ${ }^{26}$.

Средние рыночные цены в Крыму в июле (в период их временной стабилизации) равнялись: фунт пшеничного хлеба стоил 135 руб., пуд муки-сеянки 4300-6000 руб., фунт говядины подешевел на 50 руб., составляя 900 руб., фунт сливочного масла - 3650 руб. (также подешевел в сравнении с июнем (3200 руб.)), кварта молока - 350 руб., десяток яиц - 1100 руб., фунт сахара-песка 1700 руб., фунт керосина - 1405 руб. ${ }^{27}$ Фактически неизменной на протяжении почти всего 1920 г. оставалась лишь цена на соль, имевшуюся в Крыму в большом количестве (цены на нее колебались от 3 до 6 руб. за фунт) ${ }^{28}$. Зерно и зернофураж расценивались следующим образом: пуд пшеницы в Крыму, в среднем, - 3000-3500 руб. В июне оптовая цена пуда пшеницы в Симферополе рав-

\footnotetext{
${ }^{24}$ ГА РФ. Ф. 879. Оп. 1. Д. 68. Лл. 28-28 об.; 44-44 об.

${ }^{25}$ Там же. Лл. 44-44 об.

${ }^{26}$ ГА РФ. Ф. 879. Оп. 1, Д. 68. Лл. 44 об. -45.

${ }^{27}$ ГА РФ. Ф. 879. ОП. 1. Д. 89. Лл. 67-71 об.; Хвойнов П.П. Указ. соч. С. 226-227.

${ }^{28}$ ГА РФ. Ф. 879. ОП. 1. Д. 84. Лл. 1-5; Хвойнов П.П. Указ. соч. С. 226-227.
} 
нялась 3000-3400 руб., ржи - 3000-3500 руб., овса - 3400-3500 руб., ячменя 3300-3600 руб. Более высоким уровнем цен при этом отличались Евпаторийский, Феодосийский уезды, более низким - Перекопский и Симферопольский. ${ }^{29}$ В Северной Таврии в это же время средние цены на зерно составляли 1500 3000 руб. за пуд пшеницы, 1300-1400 руб. за пуд ржи, 1700 руб. - пуд мукисеянки $^{30}$.

Несмотря на ведение военных действий непосредственно на территории Северной Таврии, невысокий урожай и повышенный спрос со стороны Крыма, цены здесь были еще сравнительно низкими, что позволяло регулировать спрос между этими двумя районами Таврической губернии на протяжении почти всего лета и начала осени 1920 г. В августе карточная система распределения хлеба, по существу так и не реализованная в полной мере, была отменена. Предложение хлеба в Крыму признали достаточным.

Продолжение операций Русской армии в направлениях на север (в сторону Александровска - Екатеринослава) и на северо-восток в сторону Донбасса, а также десант на Кубань давали надежды на пополнение продовольственных запасов за счет богатых хлебородных регионов. В сентябре - начале октября газеты белого Крыма отмечали большие возможности (в плане снабжения продуктами) Александровского уезда Екатеринославской губернии, где, якобы, «урожайность хлебов значительно выше среднего» (реально Екатеринославская губерния в 1920 г. давала понижение урожайности по сравнению с предшествующим 1919 г.) $)^{31}$. Ввиду кратковременности пребывания Русской Армии в этой районе снабжение продовольствием могло производиться отсюда лишь посредством захвата зерна, зернофуража сбора прошлых лет на продовольственных складах, амбарах, элеваторах в крупных городах и на железнодорожных станциях, а также реквизиций ${ }^{32}$. Но нередко из-за нераспорядительности и медлительности военной и гражданской администрации данные продовольственные запасы вывезти в Крым не успели.

Между тем, с начала сентября цены на продукты в Крыму и Северной Таврии начали расти. Вопреки традиционным сезонным колебаниям цен, когда в осенние месяцы происходило их снижение, из-за усиления военных действий, неуверенности крестьян-производителей в выгодном сбыте имевшихся излишков, а также продолжающегося стремительного падения рубля, в Таврии 1920 г. этого не произошло.

${ }^{29}$ ГА РФ. Ф. 879. Оп. 1, Д. 84. Лл. 1-2 об.; Ф. 879. Оп. 1. Д. 89. Л. 67-71 об.

${ }^{30}$ ГА РФ. Ф. 879. Оп. 1, Д. 83. Лл. 56-57; Голос фронта, Мелитополь. 23 июля 1920 г.; ГА РФ. Ф. 879. Оп. 1. Д. 68. Л. 52.

31 Челиниев А.Н. Сельскохозяйственная география России. Берлин: б.и., 1923. С. 213214; Крестьянский путь. Симферополь. 1920. 13 октября.

32 Оприи И.И. Лейб-гвардии Казачий Е. В. полк в годы революции и гражданской войны 1917-1920. Париж: Сияльский, 1939. С. 332-333. 
По сообщениям УТиП к концу сентября - началу октября цены на пшеницу в Мелитополе поднялись до 3500 руб. пуд, а за первую половину октября выросли до 6000-6500 руб., пуд ржи стоил 5000 руб., пуд ячменя - 1300 руб., пуд муки-сеянки - 10000 руб. (однако отмечалось, что воинские части платят за ячмень по 350 руб., т.е. фактически его реквизируют). ${ }^{33}$ Тем самым цены на основные зернопродукты в Северной Таврии сравнялись с уровнем Крыма и даже несколько превзошли его. Так, в начале октября пуд пшеницы стоил в Крыму 5000-5300 руб., ржи - 3500-4500 руб., пуд пшеничной муки - 9000-11000 руб., ячменя - 4300-4500 руб., овса - 3300 руб. ${ }^{34}$ Мука-сеянка расценивалась в 13000 руб. пуд, фунт сливочного масла - 7500 руб., фунт пшеничного хлеба - 300-335 руб. Яйца -4500 руб. десяток, фунт говядины - 1400 руб., кварта молока - 1500 руб. ${ }^{35}$

Но наиболее значительный скачок цен на продовольствие за весь «крымский период» произошел в конце октября, после оставления русской армией Северной Таврии. За короткий период (с 15 по 30 октября) цены выросли на $150 \%$. Перед эвакуацией из Крыма фунт пшеничного хлеба стоил в городах (наибольшие цены в Севастополе, Ялте, Керчи) около 500 руб., а в последние дни белой власти вырос до 5000 руб., пуд муки-сеянки вырос в цене до 45000 руб., фунт говядины - 1800 руб. фунт, десяток яиц - 10000 руб., кварта молока - 2500 руб., фунт сливочного масла - 20000 руб. ${ }^{36}$ Столь резкий скачок объяснялся оставлением Северной Таврии, бывшей главным источником снабжения армии, отступившей за Перекоп, и крымских городов, а также продолжающимся «обвалом» врангелевского рубля, котировки которого на Константинопольской бирже после отхода в Крым дошли до 200 тыс. рублей за 1 фунт стерлингов $^{37}$. Положение осложнялось отменой незадолго до этого системы твердых закупочных цен и таксировок, что позволяло крестьянам-производителям более выгодно реализовывать хлебные излишки на вольном рынке. Однако в самом большом выигрыше оказывались от этого спекулянты - частные торговцы и ряд кооперативных организаций, фактически монополизировавших предложение сельскохозяйственных товаров на рынке (особенно в приморских городах). Кризис продовольственного рынка после отступления русской армии из Северной Таврии стал своеобразным «падением экономического Перекопа», предтечей военного поражения белого Крыма в ноябре 1920 г. ${ }^{38}$

${ }^{33}$ ГА РФ. Ф. 356. Оп. 1, Д. 15. Л. 5.

${ }^{34}$ Крестьянский путь. Симферополь. 1920. 18 сентября.

${ }^{35}$ ГА РФ. Ф. 879. ОП. 1. Д. 84. Л. 1-5.

${ }^{36}$ Крестьянский путь. Симферополь. 1920. 18 октября; Хвойнов П. Указ. соч. С. 226-227; Раковский Г. Конец белых: От Днепра до Босфора (Вырождение, агония и ликвидация). Прага: Воля России, 1921. С. 173.

${ }^{37}$ Шафир Я. Указ. соч. С. 117-118.

38 Красный Крым. Симферополь. 1920. 9 декабря. 
Таким образом, в белой Таврии 1920 г. продолжали действовать все те же факторы, оказывавшие влияние на положение продовольственного рынка, что и на всем белом юге России 1919 г., - военный и экономический. Причем можно утверждать, что роль экономического фактора оказалась даже несколько более значимой, чем военного, поскольку, например, в защищенном «неприступным Перекопом» Крыму влияние фронта сказывалось опосредованно, а снабжение из Северной Таврии было довольно стабильным на протяжении начала осени. Но инфляция, неудовлетворенность сельского населения товарообменом рано или поздно должны были привести к кризису.

Вопросы стабилизации курса рубля стали одними из главных в повестке созванного по инициативе генерала Врангеля заседания Финансовоэкономического Совещания, в работе которого принимали участие видные деятели русского финансового мира начала века, в их числе бывший министр финансов Российской Империи П.Л. Барк ${ }^{39}$. В качестве одного из рецептов оздоровления рубля предлагалось его товарное обеспечение таврическим зерном и другими продуктами, налаживание стабильного экспорта в Западную Европу, накопление на основе этого валютных резервов ${ }^{40}$. Однако добиться этого обеспечения врангелевского рубля было возможно лишь на основании устойчивого поступления зерна от крестьян-производителей на основании выгодного для села товарообмена. Но предметы товарообмена приходилось закупать за рубежом и, несмотря на их количество, разрыв цен на промышленные и сельскохозяйственные товары продолжал сохраняться не в пользу последних ${ }^{41}$. Получался порочный замкнутый круг, выход из которого представлялся или на пути получения Правительством Юга России валютных кредитов, даже под большие проценты, (на этом, собственно, и строились расчеты финансового ведомства в сентябре - октябре 1920 г.) или через посредство изъятия у крестьян зерна на основании уплаты ими выкупных платежей за закрепляемую в собственность землю (1/5 часть урожая текущего года). Но эти расчеты не оправдались в той мере, как на это надеялись.

\section{Заключение}

Подводя итог состоянию продовольственного рынка на белом Юге России 1919-1920 гг., следует отметить, что следование принципам «фритредерства» в расчете на то, что рыночная конъюнктура сама исправит все перекосы и недостатки в продовольственном снабжении армии и тыла, оказалось совершенно несостоятельным. Пресловутая «свобода рынка» в условиях острого финансового и промышленного кризиса ничего, кроме роста спекуляции и мошенниче-

\footnotetext{
${ }^{39}$ Врангель П.Н. Указ. соч. С. 199-200.

${ }^{40}$ Юг России. Севастополь. 1920. 3 октября.

${ }^{41}$ Юг России. Севастополь. 1920. 29 сентября; ГА РФ. Ф. 879. Оп. 1. Д. 68. Л. 28.
} 
ства на белом юге России, не принесла рядовому потребителю, а крестьянинпроизводитель из-за «ножниц цен» и потерь хозяйства от войны оказался в крайне невыгодном положении. В такой ситуации естественным для расчетливого южнорусского крестьянина становился отказ от предложения продуктов своего труда на рынке. Белогвардейские правительства, отказавшись от сколько-нибудь действенных мер в отношении регулирования рынка и борьбы со спекуляцией (карточное распределение продуктов и попытки производства закупок по твердым ценам себя не оправдывали), оказывались перед перспективой потери авторитета среди большинства населения, а это не могло не сказаться на общем нестабильном положении белого фронта и тыла.

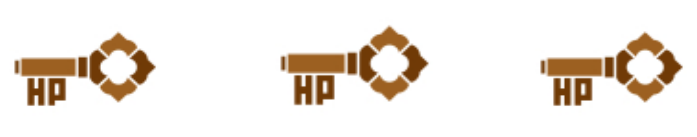

\section{Introduction}

The analysis of the economic situation in the regions occupied by the White governments still remains a by-way topic that has not been studied enough. However, for a comprehensive study of the problems related to both the history of the Civil War in Russia in general, and the White Movement in particular, it is necessary to analyse the information regarding the situation behind the lines of the White movement. This will make it possible to get an idea about the extent to which the population supported the White Power, about the prospects for the armed confrontation with the Red Army, and about carrying out certain economic policy measures, considering the regional specifics.

The economic situation in the White Crimea and Northern Taurida in 1920 was very actively studied in Russian historiography in the 1920 s and early $1930 \mathrm{~s}^{1}$. However, in the following decades, the purely economic studies were marked a decisive end. The foreign historiography did not give enough attention to the economic problems as well, limiting their studies to publications on socio-political or military-political issues ${ }^{2}$. Only in the last decades, the economic topics are once again

${ }^{1}$ Ya. Shafir, "The economic policy of the Whites (The Crimean experience)", Krasnaya nov', no. 2, 1921.; A. Gukovsky, On the history of the agrarian policy of the Russian counter-revolution (The agrarian policy of the Wrangel government), At the agrarian front, no. 7 (1927); P.P. Gensel', "The financial and economic situation in the Crimea in 1918-1920", Economist, no. 3, (1922); K. Shef, "The Crimean peninsula - the last base of the South Russian counter-revolution", War and Revolution, no. 7 (1927).

2 D. Lehovich, White against Red. The life of General Anton Denikin (N.Y.: W.W. Norton, 1974); J.D. Smele, Civil war in Siberia. The anti-Bolshevik government of Admiral Kolchak, 1918- 
getting the attention of historians ${ }^{3}$. Nevertheless, it is necessary to pay more attention to these issues. In this respect, the cooperation of historians and economists and the use of interdisciplinary links are very important.

This article thematically continues the series of the publications of the authors on the pages of 'The Economic Journal' that was issued in $2017^{4}$. It is also part of the forthcoming monograph devoted to the problems of economic, agrarian and peasant politics in the rear of the White movement in the period of 1917-20.

\section{Main Body}

There are enough sources available for this period to create a general picture for the dynamics of supply and demand in the Crimea and Northern Taurida, the growth of prices for basic food products, market conditions in the front-line regions of Northern Taurida and in the territories of the rear protected by the fortifications at Perekop in the Crimean uyezds. After the disbandment of the Food Administration, all matters related to the supply of the army and the rear in Taurida went under the supervision of the Chief Procurement Officer, Major-General P.E. Vilchevsky ${ }^{5}$. All the information on the situation at the food market is kept in the archives of the Department of Agriculture and Land Management, the Food Authority, and the Department of Trade and Industry of the State Archive of the Russian Federation (GA RF) .

The specifics of the Taurida food market in 1920 lies in the fact that in the region, contrary to the previous period of 1919, there was no extraordinary demand for any products from the more northern regions, such as Malorossiya (Little Russia) and the Central Black Earth region. Therefore, the arrangement of food supply was limited to the boundaries of the Taurida Governorate and partly the Ekaterinoslav Governorate. On the other hand, the demand for food on part of the army and the civilian population of Taurida, which grew during the Civil War (because of the influx of

1920 (Cambridge: Cambridge University Press, 1996); N.G.O. Pereira, White Siberia. The Politics of Civil War (London: Jonathan Cape, 1996); O. Figes, A people's tragedy: The Russian revolution 1891-1924 (London: Penguin Books, 1996); P. Gatrell, Russia's First World War: A social and economic history (Harlow: Pearson Education Limited, 2005).

${ }^{3}$ V.M. Rynkov, The financial policy of the anti-Bolshevik governments in Eastern Russia (Novosibirsk: Institut istorii SO RAN, 2006); V.M. Rynkov, Land authorities of the anti-Bolshevik governments in Siberia (June 1918 - December 1919). Collection of documents. (Novosibirsk: Izdatel'stvo Ippolitova, 2017); S.V. Karpenko, Essays on the history of the White movement in South Russia (1917-1920) (Moscow: Izdatel'stvo Ippolitova, 2003).

${ }^{4}$ Tsvetkov, V.Zh. and E.A. Tsvetkova, "Features of regional food markets during the Civil War in South Russia in 1919 - early 1920", Economic Journal, no. 3 (47) (2017).

${ }^{5}$ P.N. Wrangel, "Notes", in The White movement. Chronicle of the White struggle, vol. VI (Berlin: Mednyi vsadnik, 1928), 20, 41.

${ }^{6}$ Gosudarstvennyi arkhiv Rossiiskoi Federatsii (GA RF) f. 355 (Department of Agriculture and Land Management), f. 356 (Department of Trade and Industry), f. 879 (Food Authority). 
refugees from the whole European Russia, which amounted to 500,000 persons), increased by several times ${ }^{7}$.

The Wrangel government in the South of Russia anchored their high hopes for the grain reserves in connection with the need to organize the commodity exchange with foreign countries to obtain weapons, manufactory goods, fuel, agricultural implements, etc. The export of grain and other products was carried out not at the expense of the purchases from the local peasants, however, mainly, due to the kept food reserves since the First World War. Consequently, the influence of the agrarian and peasant policy on the export of products from the 'White' South Russia was insignificant. Nevertheless, according to most testaments of 'White' emigrants, investigations of the Workers' and Peasants' Red Army and the research of Soviet historians, the expectation that supply from the peasant farms would be so big that it would satisfy not only the needs of the local markets but also those of the external markets, was not justified ${ }^{8}$.

In 1920, the rates of inflation in the White Taurida reached epidemic proportion. A significant hike in the saturation of the market with unsecured currency units occurred in the winter of 1919-209. However, if in March 1920, the number of banknotes put into circulation amounted to 30 billion, by August it already grew to 50 billion. Moreover, from $15^{\text {th }}$ September to $15^{\text {th }}$ October, the Feodosia monetary fund placed an order to issue 60 billion banknotes ${ }^{10}$. This ill-considered and unreasonable financial policy undermined the economy of Taurida and was one of the main factors of the almost continuing increase in food prices, not to mention the prices for the industrial goods.

The local market continued to operate based on the principles of 'free trade' proclaimed by the government under Denikin and confirmed by order No. 59 of $25^{\text {th }}$ June 1920 by lieutenant-general Pyotr Wrangel, commander-in-chief of the Armed Forces of Southern Russia ${ }^{11}$. However, under the conditions of industrial and transport disruption, the military operations and under the influence of economic and financial factors mentioned above, the free commodity exchange acquired an increasingly speculative character in the 'White' Taurida.

In March, the prices in the Crimea increased significantly compared to their level in autumn of 1919. The average price of a funt of wheat bread was 10-15 roubles (four-six roubles in October 1919) (hereinafter referred to as the funt (pound) - an

${ }^{7}$ Krest'yanskii Put' [The Peasants' Way]. Simferopol, 11 ${ }^{\text {th }}$ September 1920.

${ }^{8}$ Ya. Shafir, "The economic policy of the Whites (Crimean experience)", in Krasnaya nov', no. 2 (1921): 111; A. Gukovskii, "On the history of agrarian policy of the Russian counter-revolution (The agrarian policy of the Wrangel government)", in At the agrarian front, no. 7 (1927): 69-75.

${ }^{9}$ Ya. Shafir, The economic policy of the Whites, 117.

${ }^{10}$ Velikaya Rossia [Great Russia]. Sevastopol, $21^{\text {st }}$ September 1920; P.P. Gensel', The financial and economic situation, 108.

${ }^{11}$ Tavricheskie gubernskie vedomosti [Tauride provincial gazette]. Simferopol, $20^{\text {th }}$ July 1920. 
old Russian unit of weight, approximately 410 grams - is used. - translator's note), a pood (16,38 kg - translator's note) of sifted flour was 695 roubles (150-200 roubles in October), a funt of beef -175 roubles ( 20 roubles), whilst butter was 850 roubles ( 250 roubles) and granulated sugar -550 roubles (65 roubles) for a funt ${ }^{12}$. With the evacuation of the Armed Forces of the South of Russia to the Crimea and the evacuation of the civilian refugees from Novorossiysk, the prices rose sharply. The increase in March was $100 \%$, in April $-130 \%$ and in May $-190 \%{ }^{13}$. The pressurised product demand, which was secured by nothing but devaluated banknotes, led to growing prices. In May, the prices for the same categories of products were as follows: 108 roubles for a funt of wheat bread, 3350 roubles for a pood of sifted flour, 750 roubles for a funt of beef, 3750 roubles for a funt of butter and 1200 roubles for a funt of granulated sugar. A funt of kerosene cost 400 roubles, ten eggs -1000 roubles, a quarter of milk -300 roubles $^{14}$. Even such an affordable product for the Crimea as anchovies (Black Sea khamsa - the main nutrition product in the Russian Army commanded by General Wrangel in April-May), cost 1000 roubles in May ${ }^{15}$.

As early as in the first days after the Novorossiysk evacuation, at the meeting of the council of Commander-in-Chief of the Armed Forces of South Russia (AFSR) General Wrangel (held on $9^{\text {th }}$ April), General Wilczewski stated that "in the Crimea, the available stock of flour allows one to assume that it would last until the new crop, provided that up to one funt per person per day is consumed". It was necessary to introduce rationing for foodstuffs. At the meeting, it was decided to prohibit baking grain products, to stop any export of cereals from the Crimea and to reduce meat consumption by introducing three fasting days per week (Wednesday, Friday and Saturday $)^{16}$. According to order No. 2959 issued by the Commander-in-Chief of the Armed Forces of South Russia dated $16^{\text {th }}$ April, a food stamps system was introduced for selling bread, and breadmaking from wheat flour was now prescribed with the addition of 200 zolotniks ${ }^{17}$.

The attempt to introduce a rationing system for bread was in fact the only attempt to restrict the principles of free trade in the 'White' South of Russia in 1919-20 (without taking into account the order on criminal liability for speculation issued by General Anton Denikin, the predecessor of Wrangel). The results of such attempts

${ }^{12}$ P.P. Khvoinov, "The workers' movement and trade unions in the Crimea in 1920", in Antanta and Wrangel (M.; Pg.: GIZ, 1923), 226-27.

${ }^{13}$ Ibid.

${ }^{14}$ Ibid; GA RF f. 879, op. 1, d. 89, 11. 67-71.

${ }^{15}$ GA RF f. 879, op. 1, d. 84, 11. 1-5; d. 89, 11. 70-71.

16 "The Beginning of Wrangelism", in The Red Archive, vol. 2 (21) (1927). M.; L.: GIZ, 179; Tavricheskie gubernskie vedomosti [Tauride provincial gazette]. Simferopol, $23^{\text {rd }}$ April 1920.

${ }^{17}$ Tavricheskie gubernskie vedomosti [Tauride provincial gazette]. Simferopol, $23^{\text {rd }}$ April 1920; P.N. Wrangel, "Notes", 31. 
turned out rather modest. The introduction of the 'card' system for bread in the calculation of one funt per person per day (this measure did not concern the army, which was supposed to enjoy the old norms of bread allowance, which was two funts of bread per person) was entrusted to the municipal government authorities. However, of all the cities in the Crimea, only in Sevastopol such card restrictions were introduced ${ }^{18}$. However, this still did not improve the food situation in the city, and bread simply began to disappear off the market. No repressive measures were taken with respect to people hiding any food products, whilst the food reserves of the city administrations were rather insignificant.

The shortage of food became one of the main reasons for the Russian army advancing in May, and its "debarkation to the of Northern Taurida"19. The need for such an advance was explained by the fact that the Crimea could only exist with the help of cartaged supply of livestock products from Northern Taurida, fuel from the Donbass regions and grain surpluses from Kuban. Therefore, without any smooth running delivery of these goods, any long-term occupancy of the army and the refugees in the isolated Crimea seemed impossible ${ }^{20}$.

Upon occupation of the fertile territories of Northern Taurida and the seizure of large food stores in Melitopol, Khorly, Skadovsk and Henichesk, it was possible to arrange the dispatch of products to the Crimea and thus to alleviate the difficulties on the food market. The increase of prices in June and in July was reduced further (27\% in June against May and only $0.5-1 \%$ in July $)^{21}$. The press published the encouraging reports regarding overcoming the grain $\mathrm{crisis}^{22}$. In senior government circles, suggestions were made about a possible large-scale export of the Tauric grain ${ }^{23}$. However, the local authorised representatives of the Department of Agriculture and Land Management and the Department of Trade and Industry, were more modest in their judgments of the situation, saying that "... the procurement prices in Northern Taurida are much lower than in the Crimea (the situation was different in 1919, when the arrival of the White movement normally meant a decrease in the "unreasonably high' prices. - Authors's note), wheat flour is offered at 2500-2750 roubles (in the Crimea - 3700 roubles) for a pood, barley flour is 250 roubles (in the Crimea, no less than 300 to 1000 roubles)..., the reserves are large, the population refuses to give their bread for money. To use the grain resources of Northern Taurida, it is obviously

${ }^{18}$ Yug Rossii [South Russia]. Sevastopol, 29 $9^{\text {th }}$ July 1920.

${ }^{19}$ Rossiiskii gosudarstvennyi voennyi arkhiv (RGVA) f. 1574, op. 1, d. 479, 11. 56, 74.

${ }^{20}$ A. Gukovskii, "Behind the lines of the 'armed forces of South Russia", in The Red archive, vol. 3 (34). The Central Archives (1929): 226; GA RF f. 356, op. 1, d. 23, 11. 8-9.

${ }^{21}$ P.P. Khvoinov, The workers' movement and trade unions in the Crimea in 1920, 226-27.

${ }^{22}$ Yug Rossii [South Russia]. Sevastopol, $30^{\text {th }}$ May 1920; Velikaya Rossia [Great Russia]. Sevastopol, $2^{\text {nd }}$ July 1920.

${ }^{23}$ Yug Rossii [South Russia]. Sevastopol, $2^{\text {nd }}$ July 1920; P.P. Gensel', The financial and economic situation in the Crimea in 1918-1920, 112. 
necessary to supply the local food organization with many goods that are fast-sellers among the rural population..." 24

A similar situation was reflected in the report of the food commissioner in the Crimea (as of June), stating that “... buying bread for money is not easy, it is impossible. The prices for bread grew incredibly. In the Perekopsky Uyezd ... as of June 10, wheat costs 1000 roubles for a pood. The peasants demand kerosene, sugar, tea, dress materials, shoes, shovels, saws and agricultural grain in exchange for bread; the landlords mainly demand machines, tools and production materials (a notable difference in the requirements of commodity exchange was that peasant farms no longer counted on having any equipment, and were content with the elementary tools of labour, and in fact, until 1914, the Taurida Governorate took the leading place in Russia in terms of supply of farm machinery for peasant farms. - Authors's note), everyone abstains from selling bread..., 25

In this situation, it was pointed out that it was possible to import part of the products from abroad. It was planned to "arrange the purchase of meat and fats from the Balkans", since the local meat reserves in the Crimea were rather small, and the purchase prices were around 25-30 thousand roubles for a pood of beef and 100-130 thousand roubles for a pood of fat (so called salo). It was supposed to carry out the activity on the commodity exchange under the terms of delivery to the Balkans of local salt, which was abundant in the Crimea. Under the same conditions, it was planned to purchase sugar abroad ${ }^{26}$.

The average market prices in Crimea in July (during the temporary price stabilization) were as follows: a funt of wheat bread cost 135 roubles, a pood of sifted flour $-4300-6000$ roubles, the price of a funt of beef fell by 50 roubles, amounting to 900 roubles, a funt of butter was 3650 roubles, which was also cheaper compared to June (3200 roubles), a quarter of milk was 350 roubles, ten eggs - 1100 roubles, a funt of sugar -1700 roubles, a funt of kerosene -1405 roubles $^{27}$. In fact, throughout the whole year of 1920, only the price of salt remained unchanged, as it was easily found in the Crimea (the prices ranged from three to six roubles per funt) ${ }^{28}$. The grain and cereal forage was evaluated as follows: a pood of wheat in the Crimea, on the average, cost 3000-3500 roubles. In June, the wholesale price of a pood of wheat in Simferopol was 3000-3400 roubles, rye cost 3000-3500 roubles, oats - 3400-3500 roubles, barley - 3300-3600 roubles. Higher price levels were observed in Eupatoria and Feodosia uyezds, whereas lower levels were fixed in Perekop and Simferopol

${ }^{24}$ GA RF f. 879, op. 1, d. 68, 11. 28-28 ob; 11. 44-44 ob.

${ }^{25}$ Ibid, 11. 44-44 ob.

${ }^{26}$ GA RF f. 879 , op. 1, d. $68,11.44$ ob. -45.

${ }^{27}$ GA RF f. 79, op. 1, d. 89, 11. 67-71 ob.; P.P. Khvoinov, The workers' movement and trade unions in the Crimea in 1920, 226-27.

${ }^{28}$ GA RF f. 879, op. 1, d. 84, 11. 1-5; P.P. Khvoinov, The workers' movement and trade unions in the Crimea in 1920, 226-27. 
uyezds $^{29}$. In Northern Taurida, at the same time, the average grain prices amounted to 1500-3000 roubles for a pood of wheat, 1300-400 roubles for a pood of rye and 1700 roubles for a pood of sifted flour ${ }^{30}$.

Despite the military operations that took place on the territory of Northern Taurida, the poor harvest and the increased demand from the Crimea, the prices there were still relatively low, which allowed regulating the demand between these two regions of the Taurida Governorate during almost the entire summer and early autumn of 1920. In August, the card system of bread rationing, which was not in fact implemented in full measure, was abandoned. The supply of bread in the Crimea was recognized as sufficient.

The northbound operations of the Russian Army (towards Aleksandrovsk and Ekaterinoslav) and to the north-east towards the Donbass, as well as the arrival to the Kuban, gave hopes for refilling food reserves at the expense of rich fertile regions. In September and early October, the newspapers of the 'White' Crimea noted great opportunities (in terms of food supply) of the Aleksandrovsk Uyezd in the Ekaterinoslav Governorate, where, allegedly, "the yield of crop for bread was much higher than average" (in fact, in 1920, the Ekaterinoslav Governorate showed a decrease in yields compared to the previous year 1919) ${ }^{31}$. Because of the short deployment period of the Russian Army in this region, the supply of food could only be obtained from this region by seizing grain, collecting grain fodder from the past years at food depots, barns and elevators in the large cities and railway stations, as well as by requisitioning. However, often due to the inefficiency and slowness of the military and civil administration, these food stocks were not taken out to the Crimea $^{32}$.

Meanwhile, since the beginning of September, the food prices in the Crimea and in Northern Taurida had started to grow. Contrary to the traditional seasonal price fluctuations, when in the autumn months there was a decrease in prices, because of intensification of the military operations, the uncertainty on part of the peasantsproducers with regards to receiving profits from the sale of the surplus available to them, as well due to the steep fall of the rouble, this did not happen in Taurida in 1920 .

According to the reports of the Department of Trade and Industry, by the end of September and early October, the price of wheat in Melitopol rose to 3500 roubles for a pood, and during the first half of October it rose further to 6000-6500 roubles for a

${ }^{29}$ GA RF f. 879, op. 1, d. 84, 11. 1-2 back side; f. 879, op. 1, d. 89, 11. 67-71 back side.

${ }^{30}$ GA RF f. 879, op. 1, d. 83, 11. 56-57; Golos Fronta [The voice of the front], Melitopol. 23rd July 1920; GA RF f. 879, op. 1, d. 68, 11. 52.

${ }^{31}$ A.N. Chelintsev, The agricultural geography of Russia (Berlin, 1923), 213-14; Krest'yanskiy Put' [The Peasants' Way]. Simferopol, 13th October 1920.

${ }^{32}$ I.I. Oprits, The Cossack regiment in the years of the revolution and the Civil War (Paris: Sijal'skij, 1939), 332-33. 
pood. Rye cost 5000 roubles for a pood, barley - 1300 roubles for a pood, sifted flour - 10000 roubles (however, it was noted that the military units paid 350 roubles for a pood of barley, meaning that, in fact, it was requisitioned) ${ }^{33}$. Therefore, the prices for basic grain products in Northern Taurida were equal to the level of the Crimea and even exceeded it. Thus, in early October in the Crimea, a pood of wheat cost 50005300 roubles, a pood of rye $-3500-4500$ roubles, a pood of wheat flour -9000 11000 roubles, barley $-4300-4500$ roubles, oats -3300 roubles $^{34}$. Sifted flour costed 13000 roubles for a pood, a funt of butter costed 7500 roubles, a funt of wheat bread - 300-335 roubles, ten eggs -4500 roubles, a funt of beef -1400 roubles and a quarter of milk -1500 roubles $^{35}$.

However, the most significant increase in food prices for the entire 'Crimean period' occurred in late October, after the Russian Army left Northern Taurida. For a short period (from $15^{\text {th }}$ to $30^{\text {th }}$ October), the prices increased by $150 \%$. Before the evacuation from the Crimea, a pood of wheat bread was worth approximately 500 roubles in the cities (with the highest prices in Sevastopol, Yalta, and Kerch), and in the last days of White Power it grew to 5000 roubles. A pood of wheat flour grew in price to 45 thousand roubles for a pood, a funt of beef was 1800 roubles, ten eggs 10000 roubles, a quarter of milk - 2500 roubles and a funt of butter -20000 roubles $^{36}$. Such a hike was explained by the abandonment of Northern Taurida, the former main source of supply to the army that retreated behind Perekop, the abandonment of the Crimean cities, as well as by the continuing 'collapse' of Wrangel's rouble. After reaching the Crimea, the exchange rate of a rouble at the exchange in Constantinople reached 200 thousand roubles for one pound sterling ${ }^{37}$. The situation was complicated by the recent cancellation of the system of firm purchase prices and ratings, which allowed peasants selling the surplus of bread in the free market in a more profitable way. However, speculators became the biggest beneficiaries of such a situation. Those were private traders and a few cooperative organizations that monopolized the supply of agricultural goods on the market (especially in the seaside cities). The crisis of the food market after the retreat of the Russian Army from Northern Taurida became a kind of 'fall of the economy in Perekop', and the forerunner of the military defeat of the White Crimea in November $1920^{38}$.

${ }^{33}$ GA RF f. 356, op. 1, d. 15, 1. 5.

${ }^{34}$ Krest'yanskii Put' [The Peasants' Way]. Simferopol, $18^{\text {th }}$ September 1920.

${ }^{35}$ GA RF f. 879, op. 1, d. 84, 11. 1-5.

${ }^{36}$ Krest'yanskii Put' [The Peasants'Way]. Simferopol, $18^{\text {th }}$ October; P.P. Khvoinov, The workers' movement and trade unions in the Crimea in 1920, 226-27; G. Rakovskii, The end of the Whites: From the Dnieper to the Bosphorus (Degeneration, agony and liquidation) (Prague, 1921), 173.

${ }^{37}$ Ya. Shafir, "The economic policy of the Whites (The Crimean experience)", 117-18.

${ }^{38}$ Krasnyi Krym [The Red Crimea]. Simferopol, $9^{\text {th }}$ December 1920. 
Thus, in 1920, the same military and economic factors that influenced the position of the food market continued to operate in the White Taurida, as well as in the entire 'White South' of Russia. Moreover, it can be said that the role of the economic factor was even slightly more significant than that of the military one, since, for example, in the Crimea protected by the 'untakable Perekop', the influence of the front was indirect, and the food supply from Northern Taurida was quite stable throughout the beginning of autumn. However, inflation and dissatisfaction of the rural population with commodity exchange was to lead to a crisis sooner or later.

The stabilization of the rouble became one of the main issues on the agenda at the meeting of the financial and economic conference, organised according to the initiative of General Wrangel. The event was attended by prominent figures of the Russian financial circles at the beginning of the century, including the former Minister of Finance of the Russian Empire, Pyotr Bark ${ }^{39}$. As one of the plans for the recovery of a rouble, it was suggested to provide its commodity collateral with the Tauric grain and other products, to establish steady exports to Western Europe and the drain on foreign exchange reserves on this basis ${ }^{40}$. However, to back Wrangel's rouble was possible only based upon a steady supply of grain from the peasant producers and the commodity exchange beneficial for rural areas. Meanwhile, all goods had to be bought abroad, and despite the amount of the goods being bought, there still existed the price gap for industrial and agricultural goods, which was not in favour of the latter ${ }^{41}$. There was vicious going round in circles, where it was only possible to break the said circle by receiving foreign currency loans by the Government of South Russia, even though at very high interest rates (this, in fact, was the calculations of the financial department in September - October 1920) or through seizures of grain from the peasants based on their redemption payments to obtain title to land (1/5 of the harvest of the current year). However, those hope were misplaced to the extent they were relied upon.

\section{Conclusion}

Summing up on the state of the food market in the White South of Russia in 1919-20, it should be noted that following the principles of 'free trade' in hope that the market situation would rectify all problems and shortcomings in the food supply for the army and the rear was completely unjustified. The much-vaunted 'economic freedom' under the conditions of the major financial and industrial crisis in the White South of Russia, brought nothing to the average consumer but the growth of speculation and fraud, whilst the farmers also came out at the short end due to the so-

\footnotetext{
39 P.N. Wrangel, “Notes”, 199-200.

${ }^{40}$ Yug Rossii [South Russia]. Sevastopol, no. 148, $3^{\text {rd }}$ October 1920.

${ }^{41}$ Yug Rossii [South Russia]. Sevastopol, $29^{\text {th }}$ September 1920; GA RF f. 879, op. 1, d. 68, 11.
} 28. 
called 'price scissors' and the losses of the households because of the war. In such a situation, it was natural for a calculating South Russian peasant to refuse supplying the products of their labour to the market. The White Guard governments, refusing to take any effective measures to regulate the market and to fight the speculation (thus, the card system for product rationing and attempts to make purchases at firm prices, fell short of expectations) faced the prospect of losing credibility among the majority of the population, and that could not but had impact the overall unstable position of the White front and the rear.

\section{Список литературы}

Голдин В.И. Гражданская война в России сквозь призму лет: историографические процессы. Мурманск: МГГУ, 2012. $333 \mathrm{c}$.

Зимина В.Д. Белое дело взбунтовавшейся России. М.: РГГУ, 2005. 467 с.

Карпенко С.В. Очерки истории Белого движения на Юге России (1917-1920 гг.). М.: Издательство Ипполитова, 2005. $351 \mathrm{c}$.

Кронер Э. Белая армия, Черный барон: жизнь генерала Петра Врангеля. М.: РОССПЭН, 2011. $463 \mathrm{c}$.

Крым. Врангель. 1920 год / Сост. С.М. Исхаков. М.: Социально-политическая Мысль, 2006. $216 \mathrm{c}$.

Лубков А.В. Война. Революция. Кооперация. М.: Магистр, 1997. 262 с.

Лубков А.В., Цветков В.Ж. Белое движение в России - его программа и вожди. М.: Прометей, 2003. $189 \mathrm{c}$.

Молчанов В.А. Газетный мир антибольшевистской России. М.: Посев, 2001. 159 с.

Росс Н. Врангель в Крыму. Frankfurt-am-Main: Possev-Verlag, 1982. 376 c.

Трукан Г.А. Антибольшевистские правительства России. М.: ИРИ РАН. 2003. 255 с.

Ушаков А.И., Федюк В.П. Белый Юг. Ноябрь 1919 - ноябрь 1920 гг. М.: Аиро-ХХ, 1997. $108 \mathrm{c}$.

Фатуева Н.В. Противостояние: кризис власти — трагедия народа. Рязань: Русь, 1996. $302 \mathrm{c}$.

Федюк В.П. Белые. Антибольшевистское движение на Юге России 1917-1918 гг. М.: Аиро-ХХ, 1996. 149 c.

Цветков В.Ж. Белое дело в России. 1919 г. М.: Посев, 2009. 519 с.

Цветков В.Ж. Белое дело в России. 1919-1922 гг. Ч. 1. М.: ИП Цветкова, 2013. 496 с.

Figes O. A people's tragedy: The Russian revolution 1891-1924. L.: Jonathan Cape, 1996. $923 \mathrm{p}$.

Gatrell P. Russia's First world war: A social and economic history. Harlow: Pearson Education Limited, 2005. $318 \mathrm{p}$.

Lehovich D. White against Red. The life of general Anton Denikin. N.Y.: W.W. Norton, 1974. $320 \mathrm{p}$.

Pereira N.G.O. White Siberia. The Politics of Civil War. London: McGill-Queen's University Press, 1996. $262 \mathrm{p}$.

Smele J.D. Civil war in Siberia. The anti-Bolshevik government of Admiral Kolchak, 19181920. Cambridge: Cambridge University Press, 1996. 759 p. 


\section{References}

Fatueva, N.V. Protivostoyanie: krizis vlasti - tragediya naroda [Confrontation: A crisis of power is the tragedy of a nation]. Ryazan: Rus', 1996. 302 p. (In Russian)

Fedyuk, V.P. Belye. Antibolshevistskoye dvizhenie na Yuge Rossii v 1917-1918 [The Whites. The anti-Bolshevik movement in South Russia in 1917-1918]. Moscow: Airo-XX, 1996. 149 p. (In Russian)

Figes, O. A people's tragedy: The Russian revolution 1891-1924. London: Jonathan Cape, 1996. $923 \mathrm{p}$.

Gatrell, P. Russia's First World War: A social and economic history. Harlow: Pearson Education Limited, 2005. 318 p.

Goldin, V.I. Grazhdanskaya voina v Rosii skvoz' prizmu let: istoriograficheskie protsessy [The Civil War in Russia through the prism of years: Historiographic processes]. Murmansk: MGGU, 2012. 333 p. (In Russian)

Karpenko, S.V. Ocherki istorii Belogo dvizheniya na Yuge Rossii (1917-1920) [Essays on the history of the White movement in South Russia (1917-1920)]. Moscow: Izdatel'stvo Ippolitova, 2005. 351 p. (In Russian).

Kroner, E. Belaya armiya, Chernyi baron: zhizn' generala Petra Vrangelya [The White Army and 'Black Baron': The life of General Pyotr Wrangel]. Moscow: ROSSPEN, 2011. 463 p. (In Russian)

Lehovich, D. White against Red. The life of General Anton Denikin. N.Y.: W.W. Norton, 1974. 320 p.

Lubkov, A.V., and V.Zh. Tsvetkov. Beloye dvizhenie v Rossii - ego programma $i$ vozhdi [The White Movement in Russia - its doctrine and leaders]. Moscow: Prometheus, 2003. 189 p. (In Russian)

Lubkov, A.V. Voina. Revolyutsiya. Kooperatsiya [War. Revolution. Cooperation]. Moscow: Magistr, 1997. 262 p. (In Russian)

Molchanov, V.A. Gazetnyi mir antibolshevistskoi Rossii [The newspaper scene of the antiBolshevik Russia]. Moscow: Posev, 2001. 159 p. (In Russian)

Pereira, N.G.O. White Siberia. The Politics of Civil War. London: McGill-Queen's University Press, 1996. 262 p.

Ross, N. Vrangel v Krymu [Wrangel in the Crimea]. Frankfurt-am-Main: Possev-Verlag, 1982. 376 p. (In Russian)

Smele, J.D. Civil war in Siberia. The anti-Bolshevik government of Admiral Kolchak, 1918 1920. Cambridge: Cambridge University Press, 1996. 759 p.

The Crimea. Wrangel. The year 1920; Complied by S.M. Iskhakov. Moscow: Sotsial'noPoliticheskaya Mysl', 2006. 216 p. (In Russian)

Trukan, G.A. Antibolshevistskie pravitel'stva Rossii [The anti-Bolshevik governments of Russia]. Moscow: IRI RAS, 2003. 255 p. (In Russian)

Tsvetkov, V.Zh. Beloe delo v Rossii. 1919 [The White movement in Russia. 1919]. Moscow: Posev, 2009. 519 p. (In Russian)

Tsvetkov, V.Zh. Beloe delo v Rossii. 1919-1922 [The White movement in Russia. 1919-1922]. Part 1. Moscow: IP Tsvetkova, 2013. 496 p. (In Russian)

Ushakov, A.I., and V.P. Fedyuk, Belyi Yug. Noyabr' 1919 - Noyabr' 1920 [The White South. November 1919 - November 1920]. Moscow: Airo-XX, 1997. 108 p. (In Russian)

Zimina, V.D. Beloe delo vzbuntovavsheisya Rossii [The White movement and the rebellious Russia]. Moscow: RGGU, 2005. 467 p. (In Russian) 